\title{
Gadai Emas Prespektif Kepatuhan Syariah dan Hukum di Indonesia
}

\author{
Musa \\ UIN Sunan Kalijaga Yogyakarta \\ mustopamusa349@gmail.com
}

\begin{abstract}
In the practice of gold pawning in Islamic banking there are several costs that must be burden by customers. These costs include ujrah, administration, stamp duty, and insurance. Gold pawning transactions in Islamic banking must be identified whether they are in accordance with the concept that was stated or not. On the other hand, the practice of gold pawning is different from the policies issued by DSN. This study aims to determine the review of Islamic compliance and Islamic law against gold pawning in Islamic banking. The research method used is to use literature review, which is taken from books, articles, internet, and opinions of experts in their fields. Viewed from the aspect of sharia compliance, the reality of sharia banks uses as in the theory of sharia compliance policies in the gold mortgage financing process, namely the process of selling collateral and excess sales. While viewed from the aspect of Islamic law, the merging of the rahn and ijarah contracts is related to ta'alluq where the rahn contract is interdependent with the ijarah contract. The matter is permitted by DSN-MUI because between the rahn contract and the ijarah contract have different objects. While seen from the hadith gold pawn contract there are two contracts in one transaction, namely rahn contract and ijarah contract. This matter is prohibited in Islamic teachings.
\end{abstract}

Keywords: Gold Pawning, Shariah Compliance, Islamic Law

\begin{abstract}
Abstrak
Dalam praktik gadai emas di perbankan syariah ada beberapa biaya yang mesti dibebankan kepada nasabah. Biaya tersebut meliputi ujrah, administrasi, materai, dan asuransi. Transaksi gadai emas di perbankan syariah mesti diidentifikasi apakah sudah sesuai dengan konsep yang difatwakan atau belum. Di sisi lain praktik gadai emas berbeda dengan kebijakan yang dikeluarkan oleh DSN. Penelitian ini bertujuan untuk mengetahui tinjauan kepatuhan syariah dan hukum Islam terhadap gadai emas di perbankan syariah. Metode penelitian yang digunakan yakni menggunakan kajian pustaka, dimana diambil dari buku, artikel, internet, dan pendapat para ahli dibidangnya. Dilihat dari aspek kepatuhan syariah, realitanya bank syariah menggunakan sebagaimana dalam teori kebijakan kepatuhan syariah pada proses pembiayaan gadai emas yakni proses penjualan barang jaminan dan kelebihan hasil penjualan. Sementara dilihat dari aspek hukum Islam, penggabungan akad rahn dan akad ijarah berkaitan dengan ta'alluq dimana akad rahn saling bergantung dengan akad ijarah. Perihal tersebut dibolehkan oleh DSN-MUI karena antara akad rahn dan akad ijarah memiliki objek yang berbeda. Sedangkan dilihat dari hadis akad gadai emas terdapat dua akad dalam satu transaksi, yakni akad rahn dan akad ijarah. Perihal ini dilarang dalam ajaran Islam.
\end{abstract}

Kata Kunci: Gadai Emas, Kepatuhan Syariah, Hukum Islam 


\section{PENDAHULUAN}

Hadirnya Islam mengajarkan kepada kita semua untuk saling tolong menolong antar sesama umat, orang mampu mesti memberikan bantuan kepada orang yang tidak mampu atau orang kaya mesti bisa menolong orang miskin. Sementara tolong menolong itu banyak bentuknya baik berupa pemberian maupun dalam bentuk pinjaman. Pada bentuk pinjaman ini, hukum Islam sangat menjaga relevansi kreditur agar tidak menimbulkan kerugian. Oleh karena itu, kreditur diperbolehkan meminta barang dari debitur sebagai jaminan utangnya. Sehingga apabila debitur itu tidak mampu melunasi pinjamannya, maka barang jaminan boleh dijual oleh kreditur. Konsep tersebut dalam fiqh Islam dikenal dengan istilah rahn atau gadai (Yanggo, 1997).

Pada hakikatnya gadai itu tidak lepas dan tidak berlebihan apabila di identikkan dengan kelompok golongan ekonomi menengah. Perihal ini dikarenakan mayoritas kelompok yang memanfaatkan jasa tersebut adalah kelompok ekonomi menengah ke bawah dengan dasar bahwa bank syariah memberikan keringanan dalam hal pinjaman untuk mendapatkan modal atau aktiva dibandingkan dengan lembaga keuangan lainnya. Keringanan yang diberikan bank syariah berupa prosedur pengajuan modal dengan cepat tanpa harus melalui tahap yang panjang dan berbelit-belit (Kusairi, 2012).

Gadai di perbankan ini adalah logam mulia seperti emas dan perak yang merupakan bentuk transaksi yang bisa digunakan. Al-Qur'an dan Al-Hadits sudah mengatakan fungsi logam mulia emas dan perak sebagai maal dan simbol aset yang disimpan (Ali, 2017). Riani juga mengatakan, selain berfungsi sebagai transaksi juga bisa dipakai untuk aktivitas investasi. Tidak hanya sebatas itu saja, emas dan perak juga dipakai sebagai sarana pembiayaan atau pemberian pinjaman. Adapun tujuan pembiayaan atau pemberian pinjaman yaitu untuk mengisi keinginan yang bersifat dadakan. Terlebih kelompok yang membutuhkan uang tunai. Oleh karena itu, kelompok yang mempunyai emas atau perak bisa dijaminkan barangnya sebagai jaminan melalui sistem gadai. Langkah yang cepat dan mudah merupakan jembatan bagi kelompok untuk segera mempunyai uang tunai. Gadai emas yaitu pembiayaan jaminan berupa emas sebagai alternatif memperoleh pembiayaan dengan mudah. Pinjaman gadai emas merupakan fasilitas pinjaman secara sekaligus atau cicilan dalam jangka waktu tertentu.

Keringanan tahap transaksi dan mendapatkan uang pinjaman yang lebih banyak dari barang tidak bergerak lainnya menjadikan pembiayaan gadai emas diminati nasabah. Fondasi operasional gadai emas tersebut mengacu pada Fatwa DSN-MUI Nomor 79 Tahun 2011 tentang Qard dengan menggunakan dana nasabah yang menggambarkan bahwa qard yaitu suatu akad penyaluran dana oleh Lembaga Keuangan Syariah (LKS) 
kepada nasabah sebagai utang piutang dengan kebijakan bahwa nasabah wajib mengembalikan modal tersebut kepada LKS pada waktu yang sudah ditentukan (DSN-MUI, 2011).

Dalam praktik gadai emas di perbankan syariah ada beberapa biaya yang mesti dibebankan kepada nasabah. Biaya tersebut meliputi ujrah, administrasi, materai, dan asuransi. Namun biaya asuransi tersebut telah termasuk dalam ujrah yang dibayarkan nasabah, tidak dibebankan secara terpisah. Transaksi gadai emas di perbankan syariah mesti diidentifikasi apakah sudah sesuai dengan konsep yang difatwakan maupun dalam teks-teks syariah. Dalam fondasi operasional yakni Fatwa DSN-MUI Nomor 25 dan 26 tentang rahn dan rahn emas perbankan syariah tidak menggunakannya sebagaimana mestinya, hanya saja pihak bank menerapkan fondasi Fatwa DSN-MUI Nomor 79 tentang qardh dengan menggunakan dana nasabah sebagai landasan operasional transaksi gadai emas. Jasa gadai emas yang dilayani perbankan syariah menggunakan dua transaksi qard dan ijarah. Sementara itu, akad qard dan ijarah dipakai secara serentak dalam gadai emas masuk dalam transaksi yang dilarang oleh Rasulullah. Perihal tersebut diperkuat oleh Fatwa DSN-MUI Nomor 26 bahwa rahn emas diperbolehkan berdasarkan prinsip akad rahn, bukan qard (Indrawati, 2015). Riani juga menambahkan bahwa produk gadai emas di perbankan syariah menerapkan 3 akad yaitu (1) akad qardh, (2) akad rahn dan (3) akad ijarah. Pembiayaan yang diberikan kepada nasabah menggunakan akad qardh, dengan objek agunan berupa emas yang diikat dengan akad rahn serta penyewaan tempat penyimpanan emas yang diikat dengan akad ijarah.

Di sisi lain praktik gadai emas di perbankan syariah berbeda dengan kebijakan yang dikeluarkan oleh DSN tersebut. Produk perbankan syariah berlandaskan pada kebijakan qard dan ijarah. Perihal ini tentu timbul pertanyaan apakah dengan berlandaskan akad qard dan ijarah sesuai dengan kebijakan yang diatur oleh DSN atau mereka yang memiliki argumen tersendiri terkait dengan penggunaan akad tersebut (Absor, Hana, \& Nur, 2019). Perihal ini menarik bagi peneliti untuk melakukan kajian secara komprehensif (Indrawati, 2015).

Berdasarkan uraian di atas, maka peneliti mengambil tujuannya yakni untuk mengetahui tinjauan kepatuhan syariah dan hukum Islam terhadap gadai emas di perbankan syariah. Penelitian ini berfokus pada gadai emas dimana kita ketahui bahwa permasalahan tersebut tidak sesuai dengan teori dan praktik yang ada yakni pada kepatuhan syariah dan hukum Islam. Sehingga penelitian ini berbeda dengan penelitian terdahulu, dimana penelitian yang dilakukan Kusairi (2012) bertujuan untuk menganalisis pemberlakukan ijarah dan proses jual beli logam emas serta mengkaji tinjauan hukum Islam terhadap mekanisme operasional gadai syariah di pegadaian syariah. Selanjutnya penelitian lain Indrawati 
(2015) bertujuan untuk mengetahui implementasi dan penerapan kepatuhan syariah pada gadai emas. Kemudian penelitian yang dilakukan Anggraina (2019) bertujuan untuk mengetahui prosedur dan mekanisme dalam pemberian pembiayaan terhadap gadai emas serta untuk mengetahui kelayakan pembiayaan produk gadai emas. Terakhir penelitian yang dilakukan Sinambela (2019) bertujuan untuk mengetahui penerapan sistem gadai emas dan untuk mengetahui risiko apa saja yang timbul pada gadai emas beserta bagaimana strategi untuk mengatasi risiko-risiko tersebut. Dari berbagai penelitian tersebut penelitian ini mempunyai kebaruan yang terletak pada bahasan penelitian mengenai akad rahn, qardh dan ijarah yang diterapkan pada gadai emas di Bank Syariah.

\section{KAJIAN LITERATUR \\ Gadai Emas}

Dalam fiqh transaksi hukum gadai disebut ar-rahn. Ar-rahn yakni jenis perjanjian untuk menahan suatu barang sebagai tanggungan utang. Ar-rahn dalam bahasa arab yakni ats-tsubut wa ad-dawam yang berarti tetap dan kekal, seperti dalam kalimat ma'un rahin yang berarti air yang tenang (Ali, 2008). Ar-rahn yakni pembiayaan dengan agunan barang bergerak yang relatif nilainya tetap seperti perhiasan emas, perak, intan, berlian, batu mulia, dan lain-lain untuk jangka waktu tertentu sesuai dengan perjanjian (Wirdyaningsih, 2007). Atau menjadikan barang yang memiliki kuantitas harta menurut pandangan syariat sebagai jaminan hutang, sementara murtahin dimungkinkan bisa mengambil sebagian manfaatnya (Al-Faifi, 2016). Selain itu, perjanjian penyerahan barang yang dipakai sebagai jaminan untuk memperoleh fasilitas pembiayaan (Ismail, 2011).

Secara syariah ar-rahn yakni harta yang dijadikan jaminan utang (pinjaman) agar dapat dibayar dengan harganya oleh pihak yang wajib membayarnya, jika rahin gagal atau berhalangan menunaikannya (Rijal, 2013). Secara umum rahn bisa diartikan yaitu menjadikan suatu benda yang bernilai (menurut syara') sebagai penguat hutang yang bisa dijadikan pembayaran seluruh atau sebagian hutangnya dengan menjual atau memiliki benda tersebut (Huda, 2011).

Ada beberapa definisi yang dikemukakan para ulama fikih mengenai rahn meliputi (Sjahdeini, 2014):

1. Ulama Mazhab Maliki mendefinisikan rahn sebagai harta yang dijadikan pemiliknya sebagai jaminan utang yang bersifat mengikat.

2. Ulama Mazhab Hanafi mendefinisikan rahn dengan menjadikan sesuatu barang sebagai jaminan terhadap hak piutang yang mungkin dijadikan sebagai pembayar hak tersebut baik seluruhnya maupun sebagiannya. 
Gadai emas yakni pembiayaan jaminan berupa emas sebagai alternatif untuk memperoleh pembiayaan dengan mudah. Pinjaman gadai emas merupakan fasilitas pinjaman secara sekaligus atau cicilan dalam jangka waktu tertentu (Soemitra, 2010).

\section{Rukun dan Syarat Gadai}

1. Rukun Gadai

a. Rahin (orang yang menggadaikan)

Orang yang sudah dewasa, berakal, bisa percaya, dan mempunyai barang yang digadaikan.

b. Murtahin (orang yang menerima gadai)

Bank atau lembaga yang dipercaya oleh rahin untuk memperooleh dana dengan jaminan barang atau gadai.

c. Marhun (objek/barang gadai)

Barang yang digunakan rahin untuk dijadikan jaminan dalam mendapatkan utang.

d. Marhun bih (utang)

Sejumlah modal yang diberikan murtahin kepada rahin atas dasar besarnya tafsiran marhun.

e. Shigat (ijab kabul)

Perjanjian antara rahin dan murtahin dalam melakukan transaksi gadai (Sudarsono, 2007).

Gadai mempunyai empat unsur yaitu: rahin (orang yang memberikan gadai), murtahin (orang yang menerima gadai), marhun (harta yang digadaikan untuk menjamin utang), marhun bih (utang). Namun, untuk memutuskan rukun gadai, ulama Hanafiyah tidak menggunakan keempat unsur tersebut, melainkan menggunakan kepada pernyataan yang dikeluarkan oleh para pelaku gadai, yaitu rahin dan murtahin. Oleh karena itu, seperti halnya dalam akad-akad yang lain, Hanafiyah mengemukakan bahwa rukun gadai adalah ijab

\section{Syarat Gadai} dan kabul yang dinyatakan oleh rahin dan murtahin (Muclish, 2017).

Selain rukun yang mesti terpenuhi dalam transaksi gadai, maka dipersyaratkan juga syarat. Syarat-syarat gadai dimaksud terdiri atas (Ali, 2008):

1. Pihak-pihak yang berakad cakap menurut hukum

Pihak-pihak yang berakad cakap menurut hukum memiliki pengertian bahwa pihak rahin (orang yang menggadaikan) dan marhun (objek/barang gadai) cakap melakukan perbuatan hukum yang ditandai dengan aqil baliqh, berakal sehat, dan mampu melakukan akad.

2. Shighat (ijab qabul)

Syarat shighat tidak boleh terikat dengan syarat tertentu dan waktu yang akan datang. Misalnya orang yang menggadaikan 
hartanya mempersyaratkan tenggang waktu habis dan utang belum terbayar sehingga pihak penggadai dapat diperpanjang satu bulan tenggang waktunya.

3. Utang (marhun bih)

a. Utang yakni kewajiban bagi yang berutang untuk membayar kepada pihak yang memberi piutang.

b. Barang yang bisa dimanfaatkan, jika tidak bermanfaat maka tidak sah.

c. Barang tersebut bisa dihitung jumlahnya.

4. Marhun (objek/barang gadai)

a. Menurut syariat Islam jaminan itu mesti bernilai dan bisa dimanfaatkan.

b. Jaminan itu mesti bisa dijual dan nilainya setara dengan besarnya hutang.

c. Jaminan itu mesti jelas dan tertentu (mesti bisa ditentukan secara khusus).

d. Jaminan itu milik sah debitur.

e. Jaminan itu mesti harta yang utuh tidak berada dibeberapa tempat.

f. Jaminan itu bisa diserahkan kepada pihak lain baik materi maupun manfaatnya.

Menurut Sayyid Sabbiq dikutip oleh Sapiudin Shidiq dalam bukunya, terdapat beberapa kebijakan syarat-syarat dalam gadai menggadai antara lain (Shidiq, 2016):

a. Orang yang menggadai dan orang yang menerima gadai itu telah dewasa.

b. Mempunyai akal yang sehat.

c. Barang jaminan ada saat akad terjadi dan bisa diserahkan.

\section{Landasan Syariah tentang Gadai}

1. Al-Qur'an
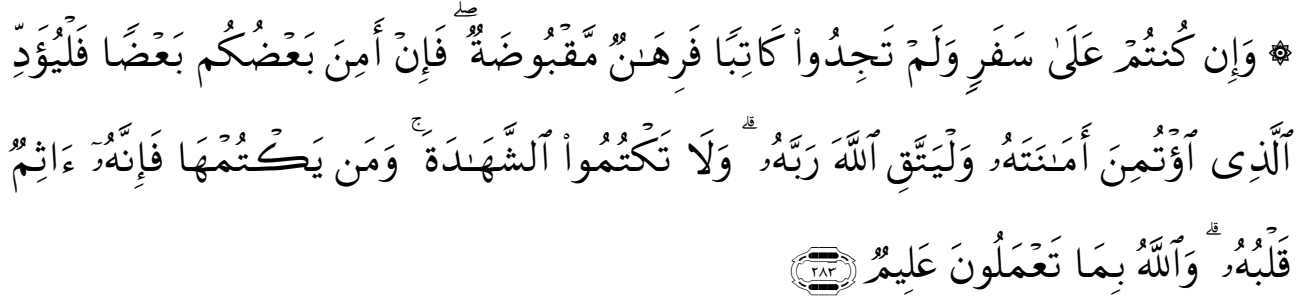

Artinya: "Jika kamu dalam perjalanan (dan bermuamalah tidak secara tunai) sedang kamu tidak memperoleh seorang penulis, maka hendaklah ada barang tanggungan yang dipegang (oleh yang berpiutang). Akan tetapi jika sebagian kamu mempercayai sebagian yang lain, maka hendaklah yang dipercayai itu menunaikan amanatnya (hutangnya) dan hendaklah ia bertakwa kepada Tuhannya; dan janganlah kamu (para saksi) 
menyembunyikan persaksian. Dan barang siapa yang menyembunyikannya, maka sesungguhnya ia adalah orang yang berdosa hatinya dan Allah maha mengetahui apa yang kamu kerjakan" (Kementerian Agama RI).

2. Al-Hadis

Dari Aisyah ia berkata: Sesungguhnya Rasulullah SAW pernah membeli makanan dengan berutang dari seorang yahudi dan nabi menggadaikan sebuah baju besi kepadanya. (HR. Al-Bukhari dan Muslim).

Hadis ini mengungkapkan bahwa gadai digunakan untuk aktivitas konsumtif oleh rasulullah, bukan untuk bisnis.

Dari Abu Hurairah Nabi SAW bersabda tidak terlepas kepemilikan barang gadai dari pemilik yang menggadaikannya. Ia memdapatkan manfaat dan menanggung risikonya (HR. Al-Syafi' i, Al-Daraquthni, dan Ibnu Majah)

3. Ijma

Dari ayat dan hadis di atas, para ulama sudah sepakat bahwasanya:

a. Sebagai agunan utang (rahn) dibolehkan (jaiz).

b. Rahn bisa dilaksanakan baik dalam bepergian (safar) maupun tidak dalam safar. Pembatasan dengan safar dalam surah albaqarah ayat 283 yakni karena kezaliman saja, maka tidak boleh diambil makna sebaliknya (mafhum mukhalafah), karena adanya hadis-hadis yang membolehkan rahn tidak dalam bepergian, disamping itu safar dalam ayat itu karena tidak diperolehnya katib (penulis), maka lazimnya tidak perlu rahn kecuali dalam safar (Djamil, 2013).

4. Fatwa DSN MUI

Fatwa DSN MUI No. 25/DSN-MUI/III/2002 tanggal 26 Juni 2002 tentang Rahn, bahwa pinjaman dengan menggadaikan barang sebagai jaminan utang dalam bentuk Rahn diperbolehkan dengan kebijakan:

a. Murtahin (penerima barang gadai) memiliki hak untuk menahan barang gadaian sampai rahin sudah melunasinya.

b. Marhun dan manfaatnya tetap menjadi milik orang yang menggadaikan. Pada dasarnya, marhun tidak boleh dimanfaatkan oleh orang yang menerima gadai kecuali atas izin orang yang menggadaikan, kemudian tidak mengurangi nilai marhun dan pemanfaatannya itu sekedar pengganti biaya pemeliharaan dan perawatannya.

c. Pemeliharaan dan penyimpanan marhun pada dasarnya menjadi kewajiban orang yang menggadaikan, akan tetapi bisa dilaksanakan juga oleh orang yang menerima gadai, sementara 
biaya tersebut tetap menjadi kewajiban orang yang menggadaikan.

d. Besarnya biaya pemeliharaan dan penyimpanan marhun tidak boleh disepakati berdasarkan jumlah pinjaman.

e. Penjualan marhun, meliputi:

1) Ketika jatuh tempo, orang yang menerima gadai mesti memberitahu kepada orang yang menggadaikan untuk segera melunasi utangnya.

2) Ketika orang yang menggadaikan tetap tidak bisa melunasinya, maka orang gadai tersebut (marhun) di jual dengan cara paksa melalui lelang sesuai syariah.

3) Kemudian hasil penjualan barang gadai tersebut dipakai untuk melunasi utang, biaya pemeliharaan dan penyimpanan yang belum dibayar serta biaya penjualaan.

4) Kelebihan uang penjualan tersebut menjadi milik orang yang menggadaikan begitupun dengan kekurangannya.

\section{Akad dalam Transaksi Gadai Emas}

1. Rahn

a. Pengertian rahn

Pada akad rahn nasabah bersepakat untuk menyimpan barang gadainnya kepada pihak bank sehingga nasabah akan membayar sejumlah fee kepada pihak bank atas biaya perawatan dan penjagaan terhadap barang gadaian (Ali, 2008).

b. Rukun rahn

1) Ada orang yang menggadaikan dan orang yang menerima gadai

2) Objek akad yakni barang jaminan dan pembiayaan

3) Ijab kabul

c. Syarat rahn

1) Pemeliharaan dan penyimpanan agunan

2) Penjualan agunan

2. Qardh

a. Pengertian qardh

Secara bahasa qardh berarti pinjaman. Secara istilah muamalah ( $T a^{\prime}$ rif) yakni memiliki sesuatu yang mesti dikembalikan dengan pengganti yang serupa Transaksi qardh pada dasarnya adalah transaksi yang bersifat umum atau bermasyarakat karena tidak diikuti dengan pengambilan keuntungan dari modal yang dipinjamkan.

b. Rukun qardh

Rukun qardh meliputi peminjam (muqtaridh), pemberi pinjaman (muqridh), jumlah dana (qardh), dan ijab qabul (shighat) (Muhammad, 2014). 
c. Manfaat qardh

1) Membantu nasabah yang kesulitan untuk mendapatkan modal talangan jangka pendek.

2) Al-qardh hasan misi sosial yang dilaksanakan oleh pihak bank, dimana kedepannya untuk meningkatkan nama bank atau reputasi bank.

3) Membantu kelompok kecil yang mau meningkatkan bisnisnya akan tetapi keterbatasan dana yang lebih besar (Aisyah, 2015) .

3. Ijarah

a. Pengertian ijarah

Secara bahasa arab sewa menyewa diartikan dengan alijarah. Menurut pengertian hukum Islam, sewa-menyewa diartikan sebagai suatu jenis akad untuk mengambil manfaat dengan jalan penggantian (Lubis, 2000). Pembiayaan yang berdasarkan akad sewa-menyewa yaitu jenis pembiayaan yang diberikan kepada nasabah yang ingin memperoleh manfaat atas suatu barang tertentu tanpa perlu memiliki (Anshori, 2008).

b. Rukun ijarah

Rukun Ijarah meliputi penyewa (musta'jir), pemilik barang (mu'ajjir), barang atau objek sewa (ma'jur), harga sewa/manfaat sewa (ujrah), dan ijab kabul (Ikit, 2018).

c. Syarat ijarah

1) Ada orang yang berakad dikriteriakan sudah baliq dan berakal.

2) Kedua belah pihak yang berakad menyatakan kerelaannya melakukan akad ijarah.

3) Manfaat yang menjadi objek ijarah mesti diketahui sehingga tidak muncul perselisihan dikemudian hari.

4) Objek ijarah itu boleh diserahkan dan digunakan secara langsung dan tidak ada cacatnya.

5) Objek al-ijarah itu sesuatu yang dihalalkan oleh syara'.

6) Yang disewakan itu bukan suatu kewajiban bagi penyewa.

7) Objek al-ijarah itu merupakan sesuatu yang biasa disewakan.

8) Upah atau sewa dalam al-ijarah harus jelas, dan sesuatu yang mempunyai nilai ekonomi (Ghazali, 2015).

\section{Kepatuhan Syariah}

Bank Umum Syariah sebagai salah satu lembaga keuangan syariah yang melaksanakan aktivitas bisnisnya berdasarkan kepatuhan syariah. Pemenuhan terhadap nilai-nilai syariah (sharia compliance) menjadi aspek 
yang membedakan dengan sistem konvensional dan syariah. Agar lebih mengenal terkait kepatuhan syariah (sharia compliance), berikut ini adalah teori-teori terkait dengan kepatuhan syariah yang didapatkan dari kajian pustaka. Menurut kebijakan Peraturan Bank Indonesia Nomor 13/2/PBI/2011 tentang Pelaksanaan Fungsi Kepatuhan Bank Umum, maka yang dimaksud kepatuhan yakni nilai, perilaku, dan tindakan yang mendukung terciptanya kepatuhan terhadap kebijakan Bank Indonesia dan peraturan perundang-undangan yang berlaku, termasuk prinsip syariah bagi bank umum syariah dan unit usaha syariah (Indrawati, 2015).

Menurut Arifin, kepatuhan syariah dalam bank syariah yakni implemantasi prinsip-prinsip Islam, syariah dan budayanya dalam transaksi keuangan dan perbankan serta usaha lain yang terkait (Arifin, 2009). Selain itu Ansori juga mengemukakan bahwa sharia compliance yakni salah satu parameter pengungkapan islami untuk menjamin kepatuhan bank Islam terhadap prinsip syariah (Ansori, 2001). Perihal itu berarti sharia compliance sebagai bentuk pertanggungjawaban pihak bank dalam pengungkapan kepatuhan bank terhadap prinsip syariah. Sedangkan Adrian Sutedi mengungkapkan bahwa makna kepatuhan syariah secara operasional yakni kepatuhan kepada Fatwa Dewan Syariah Nasional (DSN) karena Fatwa DSN merupakan perwujudan prinsip dan aturan syariah yang mesti ditaati dalam perbankan syariah (Sutedi, 2009).

Dari beberapa pengertian di atas, maka bisa disimpulkan bahwa kepatuahn syariah adalah pemenuhan terhadap nilai-nilai syariah di lembaga keuangan syariah (dalam perihal ini perbankan syariah) yang menjadikan fatwa DSN MUI dan peraturan Bank Indonesia (BI) sebagai parameter pemenuhan prinsip syariah, baik dalam produk, transaksi, dan operasional di bank syariah

\section{Ketentuan Kepatuhan Syariah}

Jaminan kepatuhan syariah atas semua kegiatan bank syariah yang merupakan aspek yang sangat penting bagi masyarakat. Adapun kebijakan yang bisa dipakai sebagai ukuran untuk menilai kesesuaian syariah di dalam lembaga keuangan syariah, meliputi (Sutedi, 2009):

1. Akad yang dipakai untuk pengumpulan dan penyaluran modal sesuai dengan prinsip-prinsip syariah yang berlaku.

2. Dana zaakt yang ditaksir dan dibayar serta dikelola sesuai dengan prinsip dan aturan syariah.

3. Semua transaksi dan kegiatan ekonomi diberitakan secara terbuka sesuai dengan pedoman standar akuntansi syariah yang berlaku.

4. Lingkungan kerja dan budaya perusahan sesuai dengan syariah.

5. Bisnis usaha yang dibiayai tidak bertentangan dengan syariah.

6. Terdapat Dewan Pengawas Syariah yang berfungsi untuk mengarahkan semua kegiatan operasional pada perbankan syariah. 
7. Sumber dana berasal dari sumber yang halal dan sah menurut syariah.

Berkaitan dengan akad gadai, ketentuan yang bisa dijadikan parameter untuk menilai kepatuhan syariah, meliputi (Soemitra, 2010):

1. Akad tidak berisi syarata batil, seperti murtahin mengkriterikan barang agunan bisa dimanfaatkan tanpa batas.

2. Marhun bih merupakan hak yang wajib dikembalikan kepada murtahin dan bisa dilunasi dengan barang yang digadaikan, serta pinjaman itu jelas.

3. Marhun bisa dijual dan nilainya sebanding dengan pinjaman, mempunyai nilai, jelas ukurannya, milik sah penuh dari rahin, tidak terkait dengan hak orang lain dan dapat diserahkan baik materi maupun manfaatnya.

4. Jumlah maksimal dana rahn dan nilai likuidasi barang yang digadaikan serta jangka waktu rahn ditentukan dalam pedoman.

5. Rahin dibebani jasa manajemen atas barang, berupa: biaya asuransi, biaya penyimpanan, biaya keamanan, dan biaya pengelolaan serta administrasi.

Kebijakan-kebijakan tersebut merupakan prinsip-prinsip umum yang menjadi pedoman bagi manajemen bank syariah dalam menjalankan bank syariah, termasuk dalam produk gadai. Kepatuhan syariah dalam operasional bank syariah dinilai berdasarkan kebijakan apakah operasional bank sudah dijalankan sesuai dengan kebijakan umum kepatuhan syariah tersebut (Sutedi, 2009).

\section{METODE PENELITIAN}

Jenis penelitian yang digunakan yakni kualitatif. Penelitian ini bertujuan untuk mengetahui tinjauan kepatuhan syariah dan hukum Islam terhadap gadai emas di perbankan syariah. Metode penelitian yang digunakan dalam penelitian ini yakni menggunakan kajian pustaka yang merupakan dengan menggunakan buku, artikel, internet dan pendapat dari ahli dalam bidang terkait yang sesuai dengan pembahasan. Penelitian ini juga mencari referensi melalui teori yang relevan sesuai dengan permasalahan yang diteliti.

\section{PEMBAHASAN}

\section{Tinjauan dari Aspek Kepatuhan Syariah}

Dalam teori gadai Islam, uang hasil penjualan tersebut dipakai untuk melunasi marhun bih dan biaya-biaya lainnya yang menjadi tanggung jawab rahin sampai batas jatuh tempo berupa biaya pemeliharaan, penyimpanan dan biaya penjualan. Kebijakan ini mengacu pada Fatwa DSN-MUI Nomor 25/DSN-MUI/III/2002 tentang rahn. Kebijakan tersebut diatur secara operasional dalam Surat Edaran Bank Indonesia Nomor 
14/7/DPbS tanggal 29 Februari 2012 perihal produk qard beragun emas. Surat edaran Bank Indonesia tersebut menggambarkan bahwa biaya-biaya yang bisa dikenakan oleh Bank syariah kepada nasabah antara lain biaya administrasi, biaya asuransi, biaya penyimpanan, dan pemeliharaan (Indrawati, 2015). Pada praktik di bank syariah, besarnya biaya pemeliharaan dan penyimpanan marhun tidak disepakati berdasarkan jumlah pinjaman. Apabila ada nasabah yang tidak melunasi kewajibannya, barang jaminan nasabah akan dijadikan untuk pelunasan hutang, yaitu melalui proses penjualan jaminan. Hasil penjualan itu akan dipakai untuk membayar biaya-biaya tersebut. Apabila uang tersebut kelebihan untuk melunasi utangnya maka kelebihan uang tersebut akan dimasukkan ke rekening nasabah atau orang yang menggadaikan dengan bukti nota kredit asli disimpan ke dalam file nasabah. Kopi file untuk disampaikan kepada nasabah melalui surat kabar. Langkah tersebut dilaksanakan oleh bank syariah sebagai berita kepada nasabah jika bank sudah menjual barang jaminan tersebut. Selain itu secara serentak dengan surat kabar tersebut diinformasikan kepada nasabah bahwa proses penjualan dan hasil penjualan sudah dipakai untuk pelunasan kewajiban nasabah. Sehingga bisa dikatakan bahwa langkah yang dilaksanakan oleh bank syariah sudah memenuhi kebijakan Dewan Syariah Nasional-Majelis Ulama Indonesia dan Bank Indonesia.

\section{Tinjauan dari Aspek Hukum Islam}

Riani mengatakan pada gadai emas bank syariah terdapat 3 akad, yakni (1) akad qardh untuk pengikatan pembiayaan dari bank kepada nasabah, (2) akad rahn untuk pengikatan emas sebagai jaminan atas pembiayaan nasabah, dan (3) akad ijarah untuk pengikatan pemanfaatan jasa penyimpanan emas sebagai jaminan pembiayaan nasabah.

Perihal ini kontradiktif dengan hadis Nabi shallallahu 'alaihi wa sallam yang diriwayatkan dari Amru bin Syu'aib bahwasanya Nabi shallahu 'alaihi wa sallam bersabda: “Tidak halal menggabungkan antara akad pinjaman dan jual beli, tidak halal dua persyaratan dalam satu jualbeli, tidak halal keuntungan barang yang tidak dalam jaminanmu dan tidak halal menjual barang yang bukan milikmu." (HR Abu Daud. Hadis ini disahihkan oleh Al-Albani).

Penggabungan akad rahn dan akad ijarah berkaitan dengan ta'alluq dimana akad rahn saling bergantung dengan akad ijarah. Meskipun DSNMUI memperbolehkan praktik ini karena antara akad rahn dan akad ijarah mempunyai objek yang berbeda. Dimana pada akad rahn yang menjadi objek yakni barang jaminannya dan objek pada akad ijarah yakni tempat sewanya. Sementara menurut Erwandi (2013) dalam penggabungan akad qardh dan ijarah, akad ijarah termasuk bagian dari akad jual-beli, karena hakikat ijarah yakni jual-beli jasa. Maka 
menggabungkan akad ijarah dan akad qardh sama hukumnya dengan menggabungkan akad jual-beli dan akad qardh, yang hukumnya terlarang.

Penelitian lain juga mengungkapkan, Habiburrahim (2012) dalam gadai emas terjadi akad rangkap, yakni gabungan akad rahn dan ijarah. Bagi peneliti akad rangkap tidak boleh menurut syara', mengingat terdapat hadis yang diriwayatkan oleh Ibnu Mas'ud RA, beliau berkata, "Nabi shallallahu 'alaihi wa sallam melarang dua kesepakatan dalam satu kesepakatan (shafqatain fi shafqatin)" (HR. Ahmad, Al-Musnad, I/398). Imam Syaukani dalam Nailul Authar juga mengomentari hadis Ahmad tersebut, "Para periwayat hadis ini yakni orang-orang kepercayaan (rijaluhu tsiqat)". Menurut Imam Taqiyuddin an-Nabhani hadis ini melarang adanya dua akad dalam satu akad, misalnya menggabungkan dua akad jual beli menjadi satu akad, atau menggabungkan akad jual-beli dengan akad ijarah (Al-Syakhshiyah Al-Islamiyah, II/308). Sistem syariah diharapkan bisa memberi kenyamanan bagi kelompok manusia dalam mendapatkan pinjaman secara halal dan sah. Gadai syariah yakni produk jasa gadai yang berdasarkan kepatuhan syariah dimana nasabah tidak dikenakan bunga atas pinjaman yang didapatkan. Dalam transaksi gadai syariah uang atau modal yang dipinjamkan berbentuk pertolongan yang tidak mengharapkan tambahan atas hutang tersebut. Perbedaan mendasar antara gadai konvensional dan gadai syariah terletak pada penerapan bunga. Untuk menghindari adanya unsur riba pada gadai syariah dalam bisnisnya pembentukan keuntungan, maka gadai syariah menggunakan prosedur yang sesuai dengan kepatuhan syariah, seperti melalui akad qardhul hasan, akad mudharabah, akad ijarah, akad rahn, akad ba'i muqayyadah, dan akad musyarakah.

Selanjutnya dalam akad gadai syariah terlihat jelas terdapat dua akad dalam satu transaksi, yaitu akad rahn (akad utang yang disertai jaminan) dan akad ijarah, satu dengan lain dikaitkan. Terdapatnya akad utang yang disertai agunan itu tidak dapat dilangsungkan kecuali disertai dengan akad ijarah yang merupakan penyimpanan barang jaminan. Sebaliknya akad ijarah penyimpanan barang agunan akan terjadi karena adanya akad jaminan yakni menjaminkan barang untuk menjadi jaminan atas utang yang didapat.

Menurut Subagiyo (2014), mengungkapkan bahwa terjadinya dua akad salam dalam transaksi bisa jadi disebabkan oleh motif dilakukannya akad utang baik qardhun ataupu dayn dalam gadai syariah. Akad qardhun dalam pandangan syariat yakni akad rifqah sebagai bentuk kasih sayang dan lemah lembut terhadap sesama. Akad qardhun itu motifnya yakni membantu dan meringankan kesulitan debitur. Akad qardhun bukan merupakan akad isttismariy (investasi). Demikian pula akad rahn bermaksud untuk menguatkan kepercayaan kreditur untuk memberikan 
utang dan sebagai jaminan utang bukan dalam rangka investasi atau untuk memperoleh keuntungan.

Namun realitanya, praktik gadai syariah telah menunjukkan bagaimana bank syariah agar tetap bisa dijadikan sebagai sarana investasi. Perihal ini terkesan bahwa niat sejak awal adalah agar gadai konvensional yang jelas keharamannya karena riba terlihat menjadi syariah dengan tetap memberikan keuntungan kepada penerima gadai. Oleh karena itu, dipakailah celah pendapat bahwa biaya perawatan rahn menjadi tanggungan rahin.

Praktik gadai syariah, kebanyakan menggunakan biaya penyimpanan, bukan biaya perawatan. Padahal penyimpanan barang jaminan oleh murtahin itu memang telah kewajiban yang timbul dari akad rahn. Kewajiban penyimpanan barang jaminan oleh murtahin secara otomatis sudah ada dan sah serta sempurna akadnya, sehingga tidak perlu di akad kan tersendiri. Disisi lain, penyimpanan rahn sebagai kewajiban murtahin yang menjadi implikasi dari akad rahn yakni tanpa tambahan biaya. Inti dari akad rahn yakni akad utang dalam praktik gadai syariah yang merupakan utang dalam bentuk qardhun yang haram menarik manfaat dalam bentuk apapun.

Apabila perlu perawatan, maka biaya perawatan ditanggung oleh pemiliknya atau perawatan terhadap barang rahn, bisa dilaksanakan oleh pihak lain untuk merawatnya. Jika yang dipekerjakan merawat bukan murtahin, maka murtahin tidak bisa mendapat biaya perawatan. Dalam realitanya, praktik gadai syariah bermotif investasi dan pembiayaan mesti mendapatkan laba. Oleh karena itu, agar laba itu bisa didapatkan oleh murtahin, maka dikriteriakan perawatan rahn mesti diujrahkan kepada murtahin, sehingga timbullah akad ijarah dan diakadkan secara serentak dengan akad rahn. Demikian tersebut akan menimbulkan dua akad dalam satu transaksi dimana tidak diperbolehkan di dalam ajaran Islam.

\section{KESIMPULAN}

Dari pembahasan di atas bisa disimpulkan bahwa praktik gadai emas di perbankan syariah dilihat dari segi kepatuhan syariah dan hukum Islam. Dilihat dari aspek kepatuhan syariah, pada realitanya bank syariah menggunakan sebagaimana dalam teori kebijakan kepatuhan syariah pada proses pembiayaan gadai emas. Pada proses penjualan barang jaminan, pihak bank syariah memberitahu kepada rahin bahwa barang tersebut telah dijualkan, perihal ini sesuai dengan syariah. Kemudian kelebihan dari hasil penjualan barang gadai tersebut diberitahu juga kepada rahin, semua kelebihan dan kekurangan jadi milik rahin, perihal tersebut sesuai dengan syariah dan teori yang ada. Sedangkan dilihat dari aspek hukum Islam, penggabungan akad rahn dan akad ijarah berkaitan dengan ta'alluq dimana akad rahn saling bergantung dengan akad ijarah. 
Meskipun demikian DSN-MUI memperbolehkan praktik ini karena antara akad rahn dan akad ijarah memiliki objek yang berbeda. Dimana pada akad rahn yang menjadi objek adalah barang jaminannya dan objek pada akad ijarah adalah tempat sewanya. Sementara dari segi hadis akad gadai emas di perbankan syariah terdapat dua akad dalam satu transaksi, yaitu akad rahn (akad utang yang disertai agunan) dan akad ijarah dan satu dengan yang lain dikaitkan. Dimana perihal ini dilarang dalam ajaran Islam.

Bank syariah diharapkan mempertahankan kepatuhan syariah yang telah terpenuhi dengan baik. Kegiatan operasional maupun produkproduk yang lain termasuk prosedur pembiayaan gadai emas diharapkan mengacu pada DSN-MUI dan peraturan-peraturan Bank Indonesia. Selain itu Dewan Pengawas Syariah di perbankan syariah agar dapat mempertahankan kinerjanya dengan baik selama ini. Selain menerapkan fatwa-fatwa DSN-MUI bank syariah diharapkan juga menerapkan hadishadis shohih terkait gadai emas.

\section{DAFTAR PUSTAKA}

Absor, C., Hana, K. F., \& Nur, F. R. (2019). Ada Apa dengan Dewan Pengawas Syariah di Koperasi Simpan Pinjam dan Pembiayaan Syariah? MALIA: Journal of Islamic Banking and Finance, 3(2), 155-173.

Aisyah, Binti Nur. (2015). Manajemen Pembiayaan Bank Syariah. Yogyakarta: Kalimedia.

Al-Faifi, Syaikh Sulaiman Ahmad Yahya. (2016). Ringkasan Fikih Sunnah Sayyid Sabbiq. Jakarta: Pustaka Al-Kautsar.

Ali, Zainuddin. (2008). Hukum Gadai Syariah. Jakarta: Sinar Grafika.

Anggraina, Dora. (2019). Analisis Kelayakan Pembiayaan Produk Gadai Emas Pada Bank Syariah Mandiri Cabang Bengkulu. Skripsi Fakultas Ekonomi dan Bisnis Islam Institut Agama Islam Negeri Bengkulu.

Anshori, Abdul Ghofur. (2008). Penerapan Prinsip Syariah. Yogyakarta: Pustaka Pelajar.

Ansori. (2001). Pengungkapan Sharia Compliance dan Kepatuhan Bank Syariah Terhadap Prinsip Syariah. Jurnal Dinamika Akuntansi, Vol. $3(2)$.

Arifin, Zainal. (2009). Dasar-Dasar Manajemen Bank Syariah. Tangerang: Aztera Publisher.

Ascarya. (2015). Akad dan Produk Bank Syariah. Jakarta: Rajawali Press.

Djamil, Fathurrahman. (2013). Penerapan Hukum Perjanjian dalam Transaksi di Lembaga Keuangan Syariah. Jakarta: Sinar Grafika.

Fatwa DSN-MUI No. 79/DSN-MUI/III/2011 tentang Qard.

Fatwa DSN-MUI No. 25/DSN-MUI/III/2002 tentang Rahn.

Ghazali, Abdul Rahman, et. al. (2015). Fiqh Muamalat. Jakarta: Kenacana. 
Huda, Qomarul. (2011). Figh Muamalah. Yogyakarta: Teras.

Ikit. (2018). Manajemen Dana Bank Syariah. Yogyakarta: Gava Media.

Indrawati, Rita. (2015). Analisis Kepatuhan Syariah Terhadap Produk

Gadai Emas (Studi Kasus Pada BNI Syariah Cabang Kusumanegara).

Skripsi Fakultas Syariah dan Hukum Universitas Islam Negeri Sunan

Kalijaga Yogyakarta.

Ismail. (2011). Perbankan Syariah. Jakarta: Kencana.

Kementerian Agama Republik Indonesia, Al-Qur'an dan Terjemahannya.

Kusairi, Ah. (2012). Konsep Gadai Emas Dalam Hukum Islam (Studi

Analisis Terhadap Mekanisme Operasional Gadai Syari'ah Di

Perusahaan Umum Pegadaian Syari'ah Pamekasan. Jurnal Al-Ihkam, Vol 7(1).

Lubis, Suhrawardi K. (2000). Hukum Ekonomi Islam. Jakarta: Sinar Grafika.

Muhammad. (2014). Manajemen Keuangan Syariah. Yogyakarta: UPP STIM YKPN.

Muslich, Ahmad Wardi. (2017). Fiqh Muamalat. Jakarta: Amzah.

Riani, Desmy. Analisa Akad Rahn dan Penerapannya Pada Produk Gadai Emas Di Bank Syariah Mandiri.

Rijal, Agus. (2013). Utang Halal, Utang Haram. Jakarta: PT Gramedia Pustaka Utama.

Shidiq, Sapiudin. (2016). Fikih Kontemporer. Jakarta: Kencana.

Sholihin, Ahmad Ifham. Pedoman Umum Lembaga Keuangan Syariah. Jakarta: PT. Gramedia Pustaka.

Sinambela, Anisya Putri Syam. (2019). Penerapan Sistem Gadai Emas Pada Cabang Pegadaian Syariah Setia Budi. Skripsi Fakultas Ekonomi dan Bisnis Islam Universitas Islam Negeri Sumatera Utara Medan.

Sjahdeini, Sutan Remy. (2014). Perbankan Syariah. Jakarta: Kencana.

Soemitra, Andri. (2010). Bank dan Lembaga Keuangan Syariah. Jakarta: Kencana.

Subagiyo, Rakhmat. (2014). Tinjauan Syariah Tentang Pegadaian Syariah (Rahn) . Jurnal An Nisbah, Vol 1(1).

Sudarsono, Heri. (2007). Bank dan Lembaga Keuangan Syariah. Yogyakarta: Ekonisia.

Sutedi, Adrian. (2009). Perbankan Syariah, Tinjauan dan Beberapa Segi Hukum. Jakarta: Ghalia Indonesia.

Wirdyaningsih, et. al. (2007). Bank dan Asuransi Islam di Indonesia. Jakarta: Kencana Prenada Media.

Yanggo, Chuzaimah T. (1997). Problematika Islam Kontemporer. Jakarta: LSIK. 